\title{
Integrating Suum-ngi Theology of Peace in Gindiri Theological Seminary Curriculum in Nigeria An African Theological Perspective
}

\section{Benjamin J. Pokol and Chammah J. Kaunda ${ }^{1}$}

\begin{abstract}
This article argues that Gindiri theological seminary in Nigeria has done little or nothing to include issues of peace in theological education for the pastors in Church of Christ in Nations (COCIN) of Nigeria. Consequently the Church of Christ in Nations seems to have failed to engage adequately in promoting peace among their members in the national search for peace and religious tolerance in Nigeria. The article further argues that the theological seminary which produces pastors and lay church leaders for pastoral ministry has a responsibility to equip pastors with necessary tools for responding to peace challenges facing the country. Therefore, the article advocates for the mainstreaming of Suum-ngi theology of peace in the curriculum of Gindiri Theological Seminary.
\end{abstract}

Key words: Suum-ngi theology of peace, Kadung, Church of Christ in Nations, Gindiri Theological Seminary, Nigeria

\section{Introduction}

It is no news that since independence in 1960, Nigerians have been experiencing series of religio-political violence (Higazi, 2011:5-10). These violent conflicts are engendered by various factors such as religious, political, regional, or economic competitions (Awoniyi, 2012:595). However, religious conflicts have been at the center-stage in the last few decades as Christians and Muslims struggle for the political space (Lesmore, 2015:148). It is also important to stress that the failure of the successive Nigerian governments to establish good government, forge national integration and promote what can be called real economic progress, through deliberate and articulated policies, has led to mass poverty and unemployment in the nation (Salawu, 2010:348). This has resulted into communal, ethnic, religious, and class conflicts that have characterized the Nigerian nation. Nkurunziza Colletta (1996:v) attributes the causes of violent conflicts in Nigeria to 'poverty, lack of clear vision, unmotivated staff, limited resources, lack of transparency and accountability, inequality, ethnic and political discrimination'. On his part, Benson

1 Dr Benjamin Pokol and Dr Chamma Kaunda are with the School of Religion, Philosophy and Classics, University of KwaZulu-Natal 
Igboin (2012:8-9) calls on the church to 'constitute an independent commission of enquiry to probe the instigators of the violence because for the church to do less than this minimum demand, apparently betrays the prophetic office, which is a consciousness that brings about God's "politics of justice"'. Lamenting the prophetic silence of the Nigerian church, Igboin (2012:9) notes that: 'The tonality of the prophetic demand has led to scarcity of prophets, and where some exist, they tactfully evade prophesying because of what Ukwuegbu describes ${ }^{2}$ concerning the church's role in the society.' In line with the call on the church in Nigeria to re-awaken her prophetic vocation in all dimensions, the Report of the International Ecumenical Peace Convocation of May 2011 in Kingston, Jamaica (Chunakara, 2013:43), calls on the churches to identify the everyday choices that can end the abuse and promote human rights, gender justice, economic justice, unity and peace...peace education must move to the centre of curriculum while the churches are called to go public'.

While poverty and unemployment have served as nursery bed for the incessant conflicts in Nigeria, the prophetic voice of the church seems to be silent (Salawu, 2010:348). As a result, the church has not only adequately promoted peace in Nigeria but has failed to utilize her prophetic voice by side-lining to mainstream theology of peace through its seminaries to produce pastors that are sensitive to religious power-dynamics in the Nigerian society. This failure has led to the production of pastors who are not adequately prepared to engage in issues of peace in the nation. It is in view of this that this article calls for mainstreaming Suum-ngi theology of peace in the curriculum of Gindiri Theological Seminary (hereafter Gindiri) of the Church of Christ in Nations (COCIN).

Mike Oye (2007:4) observes that 'the source of a river is better than the river itself because it determines how the river goes.' In a similar way a theological seminary is the source of pastors. In other words, what pastors say and teach in their congregations is determined by the content and methodologies they learned from the seminaries. The seminary has some level of responsibility to equipping pastors and lay church leaders for public peace-building. Therefore, mainstreaming African theology of peace (suum-ngi) in the curriculum ${ }^{3}$ of Gindiri theological semi-

2 We lack the courage to dare and the energy to try new grounds. It may be because we are afraid of risking the static comforts that the status quo guarantees and ensures. We take comfort in the old-age (sic) wisdom that there is no changing a winning team, without a critical assessment of whatever we regard as winning at all, and winning for all.

3 The term curricula are plural of curriculum. Babalola Fafunwa (1973) defines curriculum as "s a set of learning experiences open to learners under the guidance of schools. He goes further to expand it to include the content of all values that a society cherishes and passes it from generation to generation. In this context, seminaries have their curricula which are the total contents of learning experiences used in equipping pastors and other lay leaders of the church. Such curricula are expected to be 
nary is significant because it appeals to traditional wisdom and philosophy of the local people. Gindiri area within which the seminary is located is a suburb within Plateau Region of Nigeria. This context is coloured by religious conflict. So for the seminary to contribute adequately to promotion of peace, it is not just any kind of peace that must be integrated in its curriculum but contextually informed form of peace. This is a kind of peace that is informed by the worldview and experiences of the local people. This article suggests suum-ngi principle which is a creation worldview of the Kadung ethnic group a cultural context where Gindiri is located in Nigeria. Suum-ngi refers to the humanity or human-ness and the essence of being human and the basis of the wholeness of the community which is also shared by both the Kadung Christians and the Kadung Muslims (Lusa, 2010:24). The choice to integrate Suum-ngi notion of peace in Gindiri Theological Seminary Curriculum is because of its relevance to the Nigerian society as a context inhabited by Africans with Bantu ancestry lineage. Gindiri is very strategic because it is responsible for training most of the pastors with many of them from the Kadung ethnic group. It is also because the religio-political violent conflict is intra-state violence which is more pronounced within the context where the Kadung ethnic group is found and the perpetrators share the same culture and suum-ngi as their worldviews. Suum$n g i$ underlies and embraces all that African theology of peace is about.

\section{Grounding Peace within African Theological Approach}

African theology calls for wholistic and wholesome human relationship that is based on, and in line with, the desire of the creator to see that the entire creation flourished (Kaunda 2014). This is the foundation on which African theology is articulated in relation to different sociocultural contexts and contemporary issues that challenge and inhibit human realization of that which holds them together. African theology has been defined by Chammah Kaunda (2014:97) as the articulation of the Christian faith by African Christians in the light of their history, culture and contemporary issues in order to transform life-denying and death-dealing situations emerging from either the church or another quarter. This is a very important definition because it takes into consideration the context of Africans and their contemporary issues which in most cases undermine the humanity of the majority of Africans. Kaunda (2012:144) further argues that "the notion of just peace cannot be dealt with from isolation but within the cultural milieu of a particular people". Africans are religious-centered, which is significant in the realization of just peace... since all human life is perceived as the outflow of a God who is the

wholistic, covering relevant disciplines that will enable their products to actively respond and address social challenges that confront societies. 
ultimate source and originator of life, life is regarded as sacred, which must not be interrupted but kept within its intricate balance through harmonious living" (Kaunda 2012:144-145). The recognition of both God and common humanity are cardinal points in suum-ngi notion of peace and can contribute to constructing an African informed theology of peace for Gindiri theological seminary. Audu Lusa (2010:3) also describes African theology of peace as 'Africans recognizing their one-ness, their common origin as human beings, working to protect and promote the realization of their one-ness in joy and in pain, and doing everything possible to safe-guard their common dignity'. Of course, community is in the African blood because loneliness is considered death (Lusa, 2010:14).

African theology of peace is grounded in African tradition, philosophy, and wisdom as African culture is based on the quest for communal wholeness and peaceful coexistence (Duhm, 2007:3). African culture is best understood from Duhm's description of a natural community:

A natural community is like an organism, and the individual people and groups are its organs. The organs of a healthy organism have different tasks and functions... and yet they belong to the same organism. When living in such organism, people gradually stop living according to principles of comparison and competition, and start living according to principles of supplementing and supporting each other...The system could not work otherwise... the communitarian 'I' replaces the individual 'I', and they can access survival abilities that they would not have as individuals.

Peace, for Africans, is peace of and for the whole community for which each individual is obliged to sustain or preserve together as a web thread of that particular community. The community exists as a web of life in which each individual participates (Kaunda 2012).

\section{The Gindiri Theologiacl Seminary}

Gindiri $^{4}$ Theological Seminary was established in 1934 by the Sudan United Mission (S.U.M.) British Branch, the founding fathers and mothers of the Church of Christ in Nations (COCIN hereafter COCIN). The COCIN functions within evangelical tradition and the seminary is evangelical in its theological approach (Light Bearer, 1907:2-5). It is named after the suburb called Gindiri within Mangu Local Government Area in Plateau Region of Nigeria, where the early missionaries settled in the early 1930s. Within this suburb is also a cluster of secondary schools belonging to

4 Etymologically, according to an oral source (Hamisu, 2015), the meaning of Gindiri is a very high black volcanic rock East of the Gindiri settlement which the indigenous people used to call "zhindiri" but when the white missionaries came, they could not pronounce the word and hence "Gindiri". 
the COCIN. This old missionary compound has produced most of the elite for the state because of its long history and location within the centre of Nigeria (Dung, 2013:144-145).

The seminary has evolved from being a Bible school to a pastors' college from 1970 to 1984. It changed to a Bible College from 1986-1993 and became a college of theology from 1993 to 2011. It was renamed as Gindiri Theological Seminary in 2012 in order to contextualize it within the life of the local context (Mohzo, 2013:109). What remains to be discovered is whether the change in name would be reflected in the character of the curriculum in order to match with the emerging contextual challenges such as religious conflict in Plateau Region of Nigeria. Mohzo notes that:

The curriculum of the seminary was diversified into many strands to include literacy, a theological cum academic content, and modern agricultural training, among others. The wholistic approach was predicated on the fact that the trainees who were being trained as Evangelists were going to be church workers on regular salary...the diversified nature of the curriculum was put in place to prepare trainees on how to serve as Evangelists who would also be self-reliant in food production (2013:106).

One hardly see what is called "diversified curriculum" in the above argument because a wholistic curriculum should enable individuals become transformed through finding interconnection with themselves, communities, environment by becoming instruments of compassion and peace in the world. This curriculum stands in need of outward-looking to prepare for new challenges rather than being inward-looking. Mohzo (2013:107) underlines the philosophy of the seminary as follows:

1. To help trainees reconcile their Christian profession and biblical faith.

2. To be tools in the hands of God for the transformation of the lives of the trainees.

3. To mould the students as future leaders of the church and produce a crop of leaders that could stand future challenges, a leadership that would be strong and reliable.

4. To train religious instructors for both church and government schools.

From the above philosophy of training, one could see clearly that the emphasis is more on raising leaders than impacting the society in concrete terms. The philosophy does not include aspects of peace that are urgently needed in Nigeria. This is a sign-post of churches and their seminaries that are leader-centered with an elitist posture instead of being service-centered. Even when it changed its name to a Theological Seminary in 2012, its vision and mission statements do not reflect 
anything much in terms of curriculum reviews. The vision states that: "Gindiri Theological Seminary envisions a seminary that is a center of excellence in theological education, with adequate infrastructural facilities, facilitated by well-motivated staff who are training students for wholistic ministry" (Gindiri Theological Seminary Strategic Plan for 2011-2015, 2011:6). Well-motivated staff and adequate infrastructural facilities alone do not produce pastors for "wholistic ministry". The curriculum needs to be broad-field and all-rounded. The mission statement of the seminary states that: "Gindiri Theological Seminary exists to glorify God through her services to him and humanity by providing excellent theological education for wholistic ministry" (GTS Strategic Plan for 2011-2015, 2011: 6-7).

The phrase 'wholistic ministry' is all over the place but those who know what Nigeria is passing through would want to see the seminary reflect issues of peacebuilding in its curriculum. The curriculum of the seminary begs for mainstreaming disciplines like: Peace-building, conflict resolution, gender and religion, religion and governance, Muslim-Christian relations, comparative religion, and sociology of religion. These disciplines will facilitate and equip pastors to respond to the contextual challenges that Nigerians are facing. In a society where war is everybody's tragedy and everybody's nightmare, diplomacy is everybody's business. ${ }^{5}$

The rationale for excluding the above disciplines from the seminary's curriculum may be informed by factors ranging from lack of qualified lecturers, and Evangelical social escapism ${ }^{6}$. However, the lack of qualified lecturers to teach these seems to be the main reason for excluding them. The lecturers themselves, might be victims of the same weakness from their former seminaries since most of them went to seminaries. In this regard, Cochrane et al (1991:100-101 argues that:

The church continually seeks to form its people, particularly its members and officers, in its tasks and responsibilities of mission, worship, and evangelization... But finally the goal is to maintain and promote the identity of the faith and its relevance to human life. It does not take much practical experience to know that one of the major stumbling blocks the church faces in attempting to relate to public life and practice in crisis, is the priest or minister who so often has no tools, no experience by which to understand what is needed; and therefore, no means to think theologically or pastorally and liturgically in relation to public practice and social crises. A change in the seminary will be accompanied by a change in the parish, and in the wider society.

5 Lord Strand quoted in J.L. Rasmussen, 2005. "Negotiating a Revolution: Toward Integrating Relationship Building and Reconciliation into Official Peace Negotiations", in Reconciliation, Justice, Peace and Conflict. College Park, MD: Center for Development and Management, University of Maryland,

6 A theological position usually attributed to Evangelicals in relation to their tendency to avoid participation in social transformation, which David Bosch also describes as “pietistic model” (1983:2-4). 
Unless the seminary wants to remain irrelevant in the society, mainstreaming African theology of peace in the curriculum may be beneficial for the pastors being equipped to function in Nigeria. Seminaries in crisis contexts cannot afford to continue in their past exclusive tendencies while the society burns in flames. Leslie Newbigin (1989:155) sounds a relevant warning against exclusivism by the church in pluralist contexts: 'We now know, if we are not wilfully blind and deaf, that we live in a religiously plural world in which the other great world religions show at least as much spiritual vitality as does Christianity, a world moreover in which many Europeans and Americans, disillusioned by the manifest failures of the Christian West, are turning toward the East and South for fresh ways of understanding and coping with our common human situations. To maintain, in this new situation, the old missionary attitude is not merely inexcusable but positively dangerous'. Newbigin seems to be suggesting that in order to show that the church is ready to open up for peaceful living with others she should begin with making provision for peace in theological institutions. This determines the readiness of the church to embrace others who hold to different religious views and ideology, and her willingness to promote just-peace in the world.

We face the total annihilation of all life either by environmental pollution or by nuclear disaster, and since this is a threat to all humanity, to remain alone and claim that one religious tradition and its spiritual emphasis alone has the only answer to global problems is preposterous (Samartha, 1988:315). Engagement in peace projects is no longer an option for the church in an age of daily attacks on human life and property; we need a common and united front and response through the bond of peace and unity.

\section{Suum-Ngi as Worldview of Kadung Ethnic Group}

The concept of Suum-ngi comes from the Kadung ethnic group in Plateau State, Nigeria (Lusa, 2010:4). Kadung has suffered the severest neglect in terms of the reconstruction of its history and culture (Danfulani and Maigoro, 1999:15). Recent attempts by some historians to venture into its far past have not been very successful as most of them end up by discussing aspects of Kadung history, never reaching conclusions (Danfulani and Maigoro, 1999:16-17). The etymology of the word Kadung is "better place of settlement", which implies that they have come from elsewhere in search of a better place to settle (Danfulani and Maigoro, 1999:15). The term "worldview" has been defined as the complex of beliefs and attitudes of a group concerning their origin, organization, structures, nature, religion, and interaction in the universe with particular reference to human beings (Ikenga-Metuh, 1987:45-50). A worldview, thus, tries to answer questions about the origin and nature of humanity and its place in, and relationship with, the universe (Uchendu, 
1965:74). Tony Balcomb (2013:598) also defines worldview as "the templates that govern the social construction of a symbolic universe or paradigms in which a certain kind of knowledge is allowed... the worldviews of a culture often constitute the essential identity of that culture". Suum-ngi as a worldview, therefore, serves as a lens through which the Kadung ethnic group views humanity as an organic whole that holds together regardless of what happens to it.

The Suum-ngi is a compound word - Suum means human being, and when the suffix $n g i$ is added, it means humanity, the essence of the human person right from creation, which prompts them to live in community. Suum-ngi departs from John Mbiti's idea of bumanity and Ubuntu positions which claim that we find $b u$ manity in community (cited in Mbigi, 2010:6-14). Suum-ngi claims that human beings originated from a wild yams tuber; sharing a common origin, essence, and moving to a common destination (Lusa, 2010:12). The wild yam tuber grew so large that part of it got exposed to the sun. The exposed part eventually changed to a red colour and bitter taste. The tuber eventually metamorphosed into human beings: The exposed part produced a male, while the covered part produced a female. The two parts of the tuber are also regarded as origins of weakness and strength: the male from the exposed part is identified with strength, while the female from the covered part is identified with weakness (Lusa, 2010:34). Therefore, the male is obliged to provide security and protection for the female. The female's obligations are restricted internally within the home; while the male plays external roles (Lusa, 2010:50). This myth is reflected in the way the Kadung people build their houses: the husband's room is always at the entrance of the house; and even in the bed room, when husband and wife sleep on the same bed, the husband is always at the front to protect his wife towards the wall (Lusa, 2010:16).

Concerning the existence of the other creatures, suum-ngi attributes their origin to the vine and leaves of the same yams plant (Lusa, 2010:17). Therefore, Lusa (2010:17) reveals that the relationship between human beings and the rest of creation is a symbiotic one because they originated from the same source. There is, therefore, no hierarchy or precedence and hierarchy among human beings and other creatures because, like a chicken and an egg, it is difficult to tell which one comes first, and which one is better. As the tuber depends on the leaves and the vine for its growth, so the vine and the leaves also depend on the tuber for survival. For peaceful living, this mutuality is expected to be celebrated (King in Chunakara, 2013:67). This also extends to human relations with the environment, which is what the Ecumenical Patriarch Bartholomew (cited in Chunakara, 2013:84) argues for:

... to commit a crime against the natural world is a sin. For humans to cause species to become extinct and to destroy the biological diversity of God's creation; for 
humans to degrade the integrity of the Earth by causing changes in its climate, by stripping the Earth of its natural forests, or destroying its wetlands; for humans to injure other humans with disease; for humans to contaminate the Earth's waters, its land, its air, and its life with poisonous substances: these are sins.

Therefore, the physical environment is bound up with human existence and survival because they complement each other, and whatever happens to the environment affects human life. Suum-ngi notion of peace, therefore, sees peace as a situation where there is proper and life-giving relationship between human beings and the physical environment. The fact that they originated from a common tuber calls for caring relationship. Taken as an analogy for peaceful human relations, it promotes the equality of people, and upholds the equality of human beings.

The question that arises is whether this notion of peace does not favour men over women and whether it justifies patriarchal superiority or not. According to suum-ngi, such questions tend to deny the one-ness of the tuber. If none of the parts of the plant was better or worse than the other parts (as it is), suum-ngi emphasizes the one-ness and same-ness of the tuber, regardless of its separate parts. The fact that the male, female, and other creatures originated from distinct parts only justifies variety and distinction in creation not differences (Lusa, 2010:19). Yet care must be taken in the process of retrieving this notion in order not to be seen as justifying patriarchy and male domination that is prevalent in some African societies. What happens to husbands who are protected by their wives? What about single parent-females who have their own houses, who protects them? It is even an over-statement to say that males are stronger than women. Therefore, while the worldview offers an important analogy for African theology of peace, one ought to be careful about its implications on gender issues. Below is a sketch of suum-ngi notion of peace that exemplifies the Kadung's notion of the unity of being which was also extended to nonhuman creation.

\section{Suum-Ngi as Foundation for Peace for Kadung People}

As argued above, Suum-ngi maintains that since all creation originated from the same origin, they share the same origin, the same essence, and are moving towards the same destination (Lusa, 2010: 20). This gives creation equal standing, equal identity, and equal dignity (Adu, 2012: 2). The basic implication of this for peace is that every human being possesses common humanity, common identity, common dignity and equity based on bumanity or buman-ness. This is similar to what Martin Luther King Jr. calls the single garment of destiny (in Chunakara, 2013: 67). These profound natural and organic common grounds call for peaceful living. This notion of peace speaks volumes against social constructs that divide us 


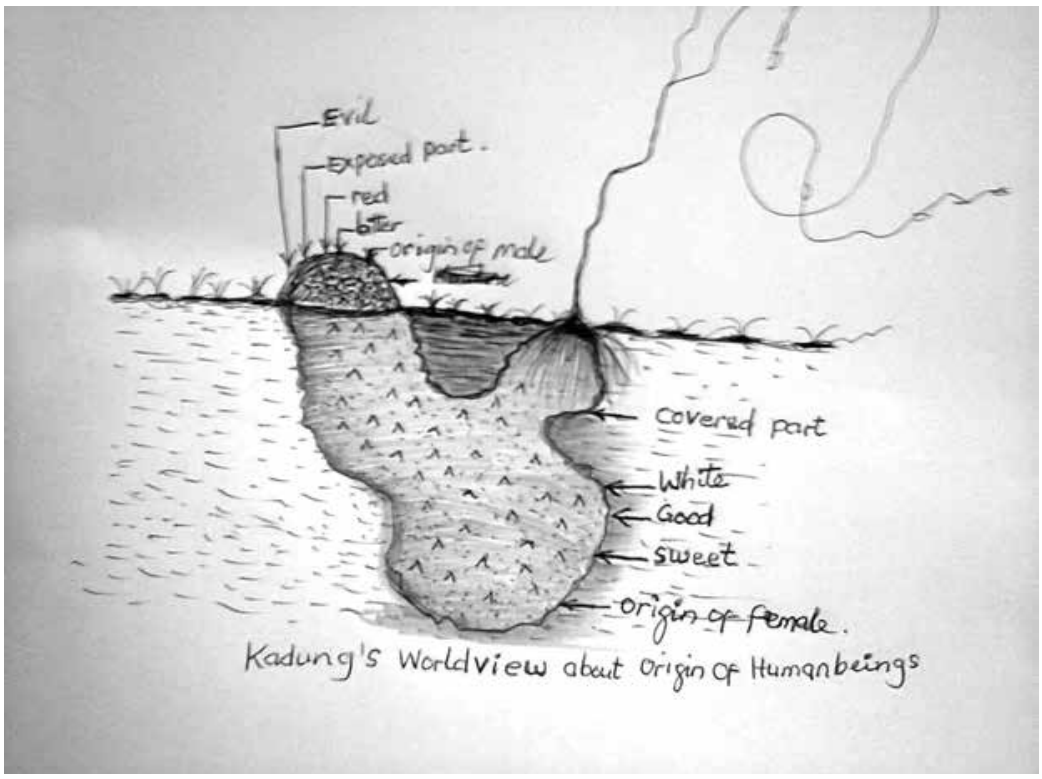

Source: Lusa's explanation of suum-ngi notion of peace (2010: 20-24).

including religion. In the suum-ngi worldview human beings and the rest of creation are so tied together that whatever happens to one happens to all (Mbiti 1990). Selfishness, greed, and hatred are not primarily violating social values but human nature. When we take off our eyes from our common origin, common essence, and common destination, we begin to value social constructs above our natural identity and dignity (Lusa, 2010:57). Mother Teresa (cited in Wallis, 2014:129) once remarked that 'if we have no peace, it is because we have forgotten that we belong to each other [and for each other]'. Suum-ngi is always sung as a reconciliation poem after inter-tribal wars in Kadungland:

Suum-ngi shan gama, ip-boh gong-gong maghi piagha wor kap mora. I-yan bbaghaka magha ko yaba sogha rami dhalla dha kap mora, I-kop diag-diag magha mu kopsora na mu dara sogha rami shembella; Adimori yighi lishem ni'm; I sha dusa bbeh, adusa shiri, a dusa kaal, a dusa yallagha, a dusa gallura, a dusa wondon; wo wari araghat, wo kena dha araghat; ko gha wo yah a mujana, kogha wo yah dhak, suum shiri yighi didam ni'm; anak-mori ghat; adimori ghat; arama dhalla mora ghat; tom mori ghat, dhaksara mori ghat. Awamaghi dhalla miwomi sha dhak ni; nungvya nikapsana shadhak. [Humanity is more than a joke; it is so deep that it can cover all of us; it is wide enough to provide space for each one of us; it is high 
enough to accommodate every one of us regardless of our different sizes. Our origin is like a chameleon; some of us are red, some as black, some are white, some are yellow, some are blue, some are green, some are mixed, but all from the same origin, and rushing to the same destination. As human race, we are like termites, coming from one mother and one father. We have the same space to occupy, common responsibilities to accomplish, and common challenges to face. What peaceful relationship cannot do for us, violent conflict and division cannot do for us either] (Lusa, 2010:60).

Suum-ngi puts human beings and nonhuman creation in the same boat and at the same level as one in essence and origin which outweighs their discovered religious beliefs, life persuasions and ideologies. The obligation for peaceful co-existence does not spring from external religious beliefs but from human essence. One can change religion, political party, cultural identities, and social status but no one can change their bumanity. No one was born with religion as inherent in him or her, but is introduced to religion, but every human being is born with their inherent $b u$ manity. The argument here is that if our understanding of what constitutes a neighbour does not transcend our ethnic, religious, and political boundaries, we debase our common bumanity and we create a situation that will continue perpetuating life-denying and death-dealing crises in the name of being religious.

\section{Suum-Ngi Theology of Peace for Gindiri Theological Seminary}

Suum-ngi serves as an alternative African model of peace-building. It is embedded in African philosophy and wisdom because it goes back radically to locate human bond of unity in creation. Suum-ngi uses an analogy that is local and contextual to seminary students to observe. It does not call for use of anything or theories outside the person. This model also goes deeper than the concept of ubuntu (Mbigi, 2005:194), mang-Djala (Deuoyo, 2014), ujamaa (Oladipo, 2003), and humanism (Oladipo, 2003). Suum-ngi worldview believes that humanity is still intact even in an individual and holds that community-basedbumanity, where one is said to be human only in the company of others (as in unbuntu, Mang-Djala, and Humanism), leads to relative bumanity because communities vary from one to the other. However, there are similarities among all the concepts because all of them are African concepts. Tracing normative humanity and its dignity, suum-ngi digs deeper into the common origin, common essence, and common destination inherent in every human being. Hence, wherever and in whatever community an individual finds him/herself, his/her identity and dignity are unchanged because the common origin, essence and destination are constant (Lusa, 2010:58). 
Hence Muslims are human beings before they practice Islam; Christians are human beings before they practice Christianity; the common ground between the two is humanity. The three conditions: common origin, common essence, and common destination are not deposited in us in varying proportions; each human being has these conditions equally. Therefore suum-ngi calls for a theology of peace based on love, compassion, kindness, forgiveness, reconciliation, tolerance, accommodation of others, service, to one another, caring for one another, and dialogue of life (Lusa, 2010:44). Religion and politics do not make bumanity. Suum-ngi theology of peace is based on the recognition of the bumanity of the other before their religion.

Suum-ngi notion is grounded in the incarnation of Jesus Christ. The incarnation articulates a God who comes to make peace with the creation. By becoming a human being, Jesus recognised the inherent value of humanity. This is an entry point to formulate African theology of peace. Incarnation theology has been taught poorly and abstractly without proper analysis of what it means in terms of God making peace with the fallen world after the fall. Why there is a church or seminary is because the gospel has to be preached. What is the content of the gospel? God himself is the content of good news; how do we know this? God himself took our form, shared in our humanity, and tabernacle with us (John 1:11).

The rate of bloodletting has reached an alarming rate. If the church does not speak out for those who are being massacred, who will? (Boesak, 2005:169). Boesak's question seems to be suggesting that peace-building is a prerequisite for development and national building. This means that peace is worth giving up all other religious endeavours in order to secure it. In short, other things can wait but not peace. Arch-Bishop Oscar Romero of El-Salvador (cited in Dear 2015: blog) once said: 'When the war is over, the hungry are fed, and the children are educated, then we can resume building the cathedral' The entire mission of the church ought to be viewed as liberating and reconstructing because as Kaunda (2013:558) argues: 'God is on the mission in Africa in order to demonstrate God's liberating and reconciling love and consequently humanize the social order by overcoming inhumanity that human beings brought on others'. Whatever is not of peace is inhumanity to humanity.

\section{Integrating Suum-Ngi Theology of Peace and Gindiri Theological Seminary Curriculum}

Integrating Suum-ngi Theology of peace in the curriculum of Gindiri is aimed at equipping pastors and theologians with tools in order to be effective in engaging in the process of peace creation and conflict resolution. It is aimed at ensuring that theologians and future pastors who are trained are able to deal with peacechallenges in their parishes and the wider society. If the church is to fulfil the aim 
of being an agent of peace, unity, and reconciliation in a deeply divided Nigerian society, integrating peace theology in the curriculum of Gindiri theological seminary is inevitable. It is also relevant and consistent with new global challenges and needs. Integrating Suum-ngi theology of peace in the curriculum also means radically overhauling the whole purpose, aim and content of theological education including the methodologies and processes by which learning takes place. The impotent values and cultures of the local context need to be deconstructed and reconstructed by going beyond the mere addition or subtraction of peace-related courses on the existing curriculum to supplanting the impotent ideologies. Priscille Djomhoue (2013:642) refers to the underlying impotent ideologies as 'hidden curriculum'. The 'hidden curriculum' ought to be replaced with more life-giving and pro-peace mind-set that accommodates all people according to the values of the kingdom of God (Matt. 9:50, Rom. 14:19, 1Cor. 7:17, Eph. 2:14, Heb. 12:14).

Integrating Suum-ngi peace theology in the curriculum involves the deliberate and collective reformulation of public policy concept of transforming the whole theological enterprise, assessing the different implications for just-peace and peace-building in the society (Djomhoue, 2013:643). It offers a pluralistic approach that values diversity in religious, political, and ethnic groups-a strategy for concrete steps towards policies and programmes that give birth to something new in all political, economic, and religious spheres so that all the diverse groups benefit from just-peace (Djomhoue, 2013:644). Integrating Suum-ngi theology of peace, therefore, means hatching, causing, inducing, provoking, exciting, and stimulating new thinking leading to reformulating and reformation of theological education based on just peace informed by an African worldview, which is both relevant and life-affirming for a pluralist Nigeria (Djomhoue, 2013:644).

The call to integrate Suum-ngi theology of peace in the curriculum of the seminary is not only necessary but a prophetic stance. This argument is also justified by the realities in Nigeria, which Peter R. Awoniyi (2012:502-505) describes: 'The Nigerian plurality calls for African theology of peace to promote inter-religious dialogue; the desire for better interaction between the religious groups; the promotion of just peace in the country; the promotion of unity of humanity; the rise of religious extremism; the politicization of religion by politicians for political ends, and the endemic religious exclusivism, particularity, and unhealthy competition between Muslims and Christians, need to be corrected through an African model of peace that focuses on the one-ness of humanity'. Martin Luther King Jr. also describes the global woes that justify a search for peace:

Through our scientific and technological genius, we have made of this world a neighbourhood and yet we have not had the ethical commitment to make of it a 
brotherhood or sisterhood. But somehow, and in some way we have got to do this. We must all learn to live together as brothers and sisters or we will all perish as fools. We are tied together in a single garment of destiny, caught in an inescapable network of mutuality. And whatsoever affects one directly affects all indirectly. For some strange reason I can never be what I ought to be until others are what they ought to be. And others can never be what they ought to be until I am what I ought to be. This is the way the universe is made; this is the way it is structured.

Nigerians need the church to be proactive in promoting peace instead of being only reactive when violence happens. Being pro-active means that the church radically reconstructs its ministry in such a way that focuses on peace-building. This should be seen in every aspect of its programmes and establishments. There should be nothing in church ministry that excludes peace-building. It is hardly justifiable for a nation like Nigeria, where almost everything portrays religious colouration, to be a victim of religious crises. God cannot be competed for because he cannot be owned by any religious group. In his sermon, Roderick Hewitt (2015) summarizes what seems to be at the centre of religious fundamentalism that denies religion of its constructive role: 'God is not the enemy of our enemies. He is not even the enemy of his enemies. If we think that God hates the same people that we hate, we can be certain that we have created him in our image. All forms of dehumanization, demonizing those who differ from us, treating our neighbours as "the others", and claiming that God is on our side alone...fanatical claims of absolute truth, doubt-free, uncritical confidence that we understand such absolute truth absolutely are responsible for all life-denying ideologies among religious people, making all religions guilty of war and violence.' It is true that when religion is placed above human life, it becomes a curse and destructive to that which it is supposed to protect. Therefore, integrating peace theology in theological education is pertinent because it may curtail some of the religious excesses that have overtaken the globe. When the church in Nigeria re-organizes her training institutions by integrating peace theology in the curricula, her pastors and other leaders will be better equipped to, and create more space for just-peace in the pluralistic Nigeria.

\section{Conclusion}

This paper has called for integrating African theology of peace in the curriculum of Gindiri Theological Seminary to equip pastors and lay church leaders for peacebuilding in Nigeria. The relevance for this argument is the prevailing violence that has be-devilled the country since independence. The article calls for integration of Suum-ngi Theology of Peace in Gindiri curriculum as a sign of resolution for the church to promote peace. This will facilitate the equipping of pastors and lay leaders of the church towards more life-giving ministry within the crisis-ridden Nigeria. 


\section{Bibliography}

Adu, J. 2012. The Kadung Cultural and Development Associations. Jos: Nasarawa Publications.

Atkins, D et al (eds) 1995. New Dictionary of Christian Ethics and Pastoral Theology. Leicester: Intervarsity Press.

Awoniyi, P.R. 2012. "Inter-religious Dialogue: Tool for peaceful co-existence in Nigeria; A religiously pluralistic nation" in Akande, Adelani A., Moses Audi, Olusayo Bosun Oladejo (eds.). Indigenization of the church in Africa: The Nigerian Situation: Essays in Honour of Rev. Dr. E A. Bamigboye. Ogbomoso: NBTS, pp.495-512.

Ayanga, H. 2008. "Waging Peace: The role of Religion in Reconciliation Process," in Gichure, P. and Stinton, D. (eds). Religion and Politics in Africa, pp. 112-123.

Balcomb, T. 2013. "Theological Education and the Relevance of Africa Worldviews-Shifting the paradigm," in Isabel A. Phiri and Dietrich Werner (eds.). Handbook of Theological Education in Africa. Dorpspruit: Cluster Publications, pp. 576-588.

Boesak, A. 2005. The Tenderness of Conscience. Stellenbosch: Stellenbosch University Press.

Caritas: 2006. A Vision for Justice and Peace, pp.144-148

Chunakara, G. 2013. Building Peace on Earth. Geneva: WCC Publications.

Church of Christ in Nations. 2013. Constitution. Jos: COCIN Publications.

Cochrane, J. et al. 1991. In word and in deed: Towards a Practical theology of Social Transformation. Pietermaritzburg: Cluster Publications.

Danfulani and Maigoro, 1999. The Kadung ofJos Plateau. Jos: Data Publishers

Djomhoue, P. "Mainstreaming Gender in Theological Institutions in Francophone Africa:

Perspectives from Cameroon," in Isabel A. Phiri and Dietrich Werner (eds.). Handbook of Theological Education in Africa. Dorpspruit: Cluster Publications, pp. 639646.

Frerich, J. 2011. "Just Peace: The right issues at the right time?" Journal of peace, research and action. Vol. 16. No. 1, pp. 4-7.

Galtung, J. 1975. "Three Approaches to peace: Peace-keeping, peace-making and peacebuilding", in Peace, War and Defence_Essays in Peace Research, pp. 282-304

Gawerc, M. 2006. "Peace-building: Theoretical and Concrete Perspectives," peace and change, Vol.31, No. 4, 435-478.

Gindiri Theological Seminary. 2011. Strategic Plan for 2011-2015. Jos: COCIN Publications.

Goshit, Z. et al. 2013. (eds.). History of the Church of Christ in Nations (COCIN) 19042013. Jos: COCIN Publications.

Gutip, N. 1998. Church of Christ in Nigeria: Birth and Growth. Jos: Crossroad Publications.

Hewitt, RR. 2015. "Locked Behind the Doors," Sunday Service Sermon, 21st June 2015, Scottsville Presbyterian Church, Pietermaritzburg.

Higazi, A. 2011. The Jos Crisis: A recurrent Nigerian Tragedy. London: Friedrich Ebert Stiflung.

Dear, J. 2015. "Honoring Oscar Romero of El Salvador," http://www.huffintonpost.com/ john-dear/bonoring-oscar-romero-of_b_7342546.htm [Accessed May 21 2015]. 
Igboin, B. 2012. "Religious conflicts in Nigeria: Towards a re-awakening of the prophetic voice" Studia Historiae Ecclesiasticae, vol 38, Supplement, pp. 223-241

Kaunda, C.J. 2012. "Towards an African Theological Education for Gender and Peace: An African Theological Reflection on the Concept of Just-peace" in Journal of Gender and Religion in Africa Vol. 18 No.1, pp. 137-153

Kaunda, CJ. 2013. "Doing Theological Education from the Context of Migration in Southern Africa: A Theology of Reconciliation in Missiological Perspective" in Isabel Apawo and Dietrich Werner (eds). Handbook of Theological Education in Africa. Dorpspruit: Cluster Publications, pp. 155-165.

Kaunda, CJ. 2014. "Theological Education in victim-offender Dialogue: An African Theological Perspective" in Journal of Theology and Religion in Africa. Vol. 38. No. 1, pp. 95-124

Kosha, A. and Robin A. (eds). 2007. Beyond You and Me. Hampshire: Gaia Education.

Lederach, J. 2005. The Moral Imagination: The Art and Soul of Building Peace. New York: Oxford University Press.

Lesmore, E.G. 2015. "Religion in the Public Space: A Nigerian Perspective" in Simone S. et al (eds.) Religious Plurality and the Public Space:Joint Christian-Muslim Theological Reflections. Geneva: Lutheran World Federation, pp. 145-152.

Lusa, A. Suum-ngi as philosophy of peace and unity among the Kadung ethnic group. Jos: Crossroad Publications.

Luther, M. 2013. 'Peace in the community: Affirming the dignity of and rights of all and nurturing values of mutuality' in Matthew G. Chunakara (ed.) Building Peace on Earth: Report of the International Ecumenical Peace Convocation. Geneva: WCC Publications, pp. 63-69.

Mugambi, J.N.K. 1995. From Liberation to Reconstruction. Nairobi: English Press.

Newbigin, L. 1989. The Gospel in a pluralist Society. London: SPCK.

Nkurunziza, D.R.K. 2003. "Conflict Transformation and Peace-building in Africa”, Afer. Vol. 45, No. 4, pp. 294-313.

Ojo, M. 2008. "Pentecostal, Public Accountability and Governance in Nigeria" in Ogbomoso Journal of Theology, vol. 8. No. 1, pp. 110-133.

Phiri, I. 2000. "Proclaiming Peace and Love: A new Role for the Christian churches in African Politics" Journal of church and state, vol.42 No. 4, pp.781-802.

Salawu, B. 2010. "Ethno-Religious Conflicts in Nigeria: Causal Analysis and Proposals for New Management Strategies” Journal of Social Sciences, Vol. 13. No. 3, pp. 345-353. 